Sains Malaysiana 49(12)(2020): 3017-3028

http://dx.doi.org/10.17576/jsm-2020-4912-13

\title{
Effect of Chenodeoxycholic Acid on the Performance of Dye-sensitized Solar Cells utilizing Pinang Palm (Areca catechu) Dye
}

(Kesan Asid Kenodeoksikolik terhadap Prestasi Sel Suria Pekaan Pewarna yang menggunakan Pewarna Pokok Pinang (Areca catechu)

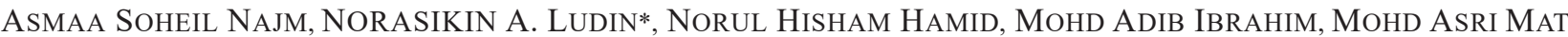
Teridi, Kamaruzzaman Sopian, Hazim Moria, AraA Mebdir Holi, Asla A. Al-Zahrani \& Hasanain SALAH NAEEM

\begin{abstract}
This study examined and described the optical and photovoltaic (PV) characterizations of the Fruit Areca catechu (pinang) as a new type of organic sensitizer. Recent reports stated that including chenodeoxycholic acid (CDCA) in the dye improves the performance of dye-sensitized solar cells (DSSCs). The effectiveness of PV dye was investigated by applying it in a DSSC. The absorption spectra indicated that natural dyes with CDCA has an excellent stabilizing ability. The Fourier-transform infrared spectra indicated the existence of carboxylic and hydroxyl functional groups in the naturally extracted dye. These functional groups were responsible for the rapid electron transfer and strong electronic linkages of interactions within the TiO, surface. In this study, photoluminescence spectra analysis showed that by narrowing the bandgap, incorporating CDCA as a co-adsorbent in natural dye could generate a significant photocurrent. The overall power conversion efficiency was enhanced by 4.6\%. Moreover, the cell efficiency reached up to $0.076 \%$ after adding $1.5 \mathrm{mM}$ of CDCA without optimizing the sensitization time. Results demonstrated that the present study contributes toward the improvement of DSSC through efficient electron injection.
\end{abstract}

Keywords: Areca catechu; chenodeoxycholic acid; DSSC; natural dye

ABSTRAK

Penyelidikan ini mengkaji dan menerangkan ciri optik dan fotovoltaik (PV) buah pinang (Areca catechu) sebagai sejenis pemeka organik yang baru. Laporan terkini menyatakan bahawa memasukkan asid kenodeoksikolik (CDCA) di dalam pemeka boleh meningkatkan prestasi sel suria pemeka warna (DSSCs). Keberkesanan pemeka PV tersebut dikaji dengan menerapkannya di dalam sel DSSC. Spektrum penyerapan menunjukkan bahawa pewarna semula jadi dengan CDCA mempunyai keupayaan menstabilkan pemeka yang sangat baik. Spektrum transformasi Fourier inframerah menunjukkan kewujudan kumpulan berfungsi karboksilik dan hidroksil dalam pewarna ekstrak semula jadi tersebut. Kumpulan berfungsi ini bertanggungjawab untuk pemindahan elektron yang cepat dan hubungan interaksi elektronik yang kuat di dalam permukaan $\mathrm{TiO}_{2}$. Dalam kajian ini, analisis spektrum cahaya menunjukkan bahawa dengan merapatkan jurang lebar, memasukkan CDCA sebagai penyerap bersama dalam pewarna semula jadi dapat menghasilkan foto arus yang signifikan. Keseluruhan kecekapan penukaran tenaga telah meningkat sebanyak 4.6\%. Selanjutnya, kecekapan sel mencapai hingga 0.076\% setelah menambahkan 1.5 mM CDCA tanpa mengoptimumkan masa pemekaan. Hasil menunjukkan bahawa kajian ini menyumbang ke arah peningkatan prestasi DSSC melalui suntikan elektron yang cekap.

Kata kunci: Areca catechu; asid kenodeoksikolik; DSSC; pewarna semula jadi

\section{INTRODUCTION}

In 1991, Grätzel and O’Regan explored using dyesensitized solar cell (DSSC) as a potential candidate for PV technology (Grätzel 2003). Well after discovery, many solar cell studies worked on DSSC. Using DSSCs addresses wide-band semiconductor insensitivity to visible light through an electron transfer sensitizer. The efficiency of DSSCs is determined by the choice of dye (effective conversion of produced photons into electricity). DSSC contains several components, including a conducting glass substrate, a mesoporous semiconductor film, a dye sensitizer, an electrolyte or mediator solution 
with a redox couple, and a counter electrode (Safie et al. 2017). The binding to the $\mathrm{TiO}_{2}$ surface and its absorbing properties dictate the cell performance (Holi et al. 2020). Several categories of dye (sensitizers) have been presented into DSSCs over the years. A thin layer of nanocrystalline $\mathrm{TiO}_{2}$ was sensitized to ruthenium complex in order to improve the performance of DSSC due to its high stability compared with other sensitizers (PortilloCortez et al. 2019). Nevertheless, the application of ruthenium in DSSC technology is limited due to the scarce and expensive nature of the element (Gürses et al. 2016; Sharma et al. 2017). To overcome these shortcomings, a number of natural dyes, such as anthocyanin, chlorophyll, tannin, and carotene, were introduced as sensitizers for DSSCs (Narayan 2012). The abundance and eco-friendly characteristics of the plants where natural dyes are extracted from appears to be more prospective in nature. Using natural dyes as sensitizers is nontoxic, commercially sustainable, and practical for improving the effectiveness to approximately $11.9 \%$ (Green et al. 2020). This strategy not only helps remediate the environmental pollution, but also promotes sustainable development. However, natural dyes also have many drawbacks, such as slow processing and low yields. In this study, we use an indigenous fruit, betel nut (Areca catechu), which is cheap and abundant, to achieve a new natural dye that can be utilized as a sensitizer for DSSCs. Betel nut contains tannin, gallic acid, polyphenols, catechin, fat, alkaloids, gum, and additional minerals that have many applications (e.g. skin anti-agents) and good antimicrobial activity. Gallotannic acid, which has a strong yellowish color, is the primary pigment of A. catechu. This pigment achieves an efficient vision absorption of the wavelength and therefore renders $A$. catechu suitable for sensitizing DSSCs (Çakar \& Özacar 2016). DSSC performance, however, is extremely low due to poor light harvesting and dye instability. Visible photons absorbed by dye molecules create charging carriers $\left(\mathrm{e}^{-}-\mathrm{h}+\right.$ pairs $)$ and then transfer electrons to $\mathrm{TiO}_{2}$ (Muhammad et al. 2016). Different forms of additives are combined with dye solutions to enhance the PV performance of fabricated DSSCs, in terms of the short circuit current density $J_{\text {sc }}$ and open-circuit voltage $V_{o c}$ of the solar cell. These additives, such as 3-phenylpropionic phosphoric acid, chenodeoxychoic acid (CDCA) and cholic acid act as co-adsorbents ( $\mathrm{Li}$ et al. 2011; Qu et al. 2010; Wang et al. 2007). CDCA, the most common and versatile co-adsorbent of the three, is a saturated, four-carbon polycyclic molecule that removes the sterol nucleus from the carboxylic acid anchoring group (Yum et al. 2008). The additive provides two main features, including the cost and good attaching capacity for mesoporous $\mathrm{TiO}_{2}$ nano-structures, which can prevent dye accumulation and transfer dye molecules to the surface of the semiconductor (Li et al. 2011). Incorporating CDCA can enhance electron transfer and inhibit dye clustering, which can improve the conversion efficiency and DSSC performance. The influence of CDCA also increases the $V_{\text {oc }}$ because of the reduced recombination impact of the charge carriers (Toor et al. 2016). On the basis of these discussion, this study evaluated the optical and PV properties of the natural sensitizer derived from $A$. catechu in DSSCs. To improve the dye aggregation, CDCA was used as a catalyst in the natural sensitizer. The photo electrochemical properties were investigated through ultraviolet (UV) spectra analysis, Fourier-transform infrared (FTIR) spectroscopy, cyclic voltammetry (CV), and photoluminescence (PL) spectroscopy. Moreover, the PV properties, such as the incident photon-to-electron conversion efficiency (IPCE) and current voltage measurement, were analyzed and enhanced. This work is a representative of the serial publication for the fabrication of DSSC from A. catechu and the second investigation after the extraction solvent is changed. The results indicated that this sensitizer guarantees the effective performance of DSSCs. The DSSC's performance with $A$. catechu 's based dye was improved by CDCA's co-adsorbent concentration effect. Furthermore, the adsorption mechanisms of CDCA on the substrate surface, energy level alignment, charge transfer, and absorption spectral evolution were used to describe the PV ability of the dye.

\section{MATERIALS AND METHODS}

\section{SOURCE OF THE DYE SENSITIZER}

This research collected the fruits of the pinang for the extraction of the new natural dye. Pinang is a member of the Plants of the Kingdom, the Arecal family, the Arecaceae family, the Areca genus and the Catechu species. The betel tree is growing in tropical Asian and Eastern African regions. The alkaloid-rich grain of $A$. catechu is normally sliced, and the endosperm is chewed as a mild stimulant. Pinang has antidepressant properties, particularly in rodents (Amarasinghe et al. 2010; Purtago et al. 2012; Shrestha et al. 2010). Moreover, A. catechu fruits contains various types of lipids, polyphenols, and sugars (Jung 2017). The most bioactive elements in $A$. catechu include polyphenols containing tannins, flavonols, and hydrolysable tannins.

\section{PREPARATION OF THE SENSITIZER FROM $A$. catech $u$}

The natural dye was prepared using the previously reported procedure (Najm et al. 2020a, 2017). First, fresh A. catechu fruits were procured from a farm located in Penang. Second, the fresh exocarps of these fruits were extracted, and the thin crusts were rinsed using distilled water before drying in an oven for $48 \mathrm{~h}$ at $45^{\circ} \mathrm{C}$. Third, a grinder (Mulry feature disintegrator SY-04) was used 
to ground the dried exocarp into fine powder. Fourth, the natural dye was extracted from the sample. Next, roughly $40 \mathrm{~g}$ of fine powder was applied to ethanol $(400 \mathrm{~mL}$ at 80 ${ }^{\circ} \mathrm{C}$ ), and the resulting solutions were then put on incubators (Ambient Shaker, SKU: SI-100) for $24 \mathrm{~h}$ to extract the dye solution. Eventually, the generated dye solution was used without further separation or filtration as a natural sensitizer for the processed DSSC.

\section{PREPARATION OF CDCA}

Four labeled conical flasks were filled with $50 \mathrm{~mL}$ of natural $A$. catechu dye. Different concentrations of CDCA powder (Solaronix; 0.1, 0.5, 1.0, and $1.5 \mathrm{mM}$ ) were then added to each flask. The obtained samples were characterized after shaking for $15 \mathrm{~min}$.

\section{FABRICATION OF DSSC}

A typical DSSC consists of a photo anode, a sensitizer, electrolyte, and a counter electrode. The fabrication process used in the present study is focused on the approach suggested by Ismail et al. (2017). Fluorine-doped tin oxide (FTO) glass with a resistivity of $8 \Omega$ /square was used as the substrate for the photo anode. The substrate was cut into $3 \times 2 \mathrm{~cm}$ and cleaned using three types of solvents (dilute acetone, dilute ethanol, and deionized water). The substrate is soaked into the solvent and washed in ultrasonic bath for $10 \mathrm{~min}$. This cycle was replicated for each solvent. Upon drying, the layer was dried using nitrogen gas or a dryer. A region of $1 \times 1 \mathrm{~cm}$ was patterned with scotch tape, and a small amount of $\mathrm{TiO}_{2}$ was deposited on top of the FTO glass substrate by doctor blade (Mahir Fariz et al. 2019). Then the layer was annealed at $500{ }^{\circ} \mathrm{C}$ for $30 \mathrm{~min}$. Following deposition, another $\mathrm{TiO}_{2}$ layer was deposited with the same technique and annealed for 30 min at $500{ }^{\circ} \mathrm{C}$. The generated thin film was treated in $\mathrm{TiCl}_{4}$ solution with a temperature at $70{ }^{\circ} \mathrm{C}$ for $10 \mathrm{~min}$ to increase the micro area of $\mathrm{TiO}_{2}$. After the treatment, the thin films were heated at $100{ }^{\circ} \mathrm{C}$ and immediately soaked into the sensitizer for 3 days to increase the amount of dye absorbed onto $\mathrm{TiO}_{2}$. The formed thin films were thoroughly cleaned using the ethanol to guarantee that no contamination is present in the $\mathrm{TiO}_{2}$, so that they can be used to fabricate the DSSC device. The FTO glass was chosen as the conducting substrate for the counter-electrode with a resistivity of 15 $\Omega /$ square. Platinum paste was applied with the doctor's blade method on top of the conducting substrate and annealed cured for $30 \mathrm{~min}$ at $450{ }^{\circ} \mathrm{C}$. The fabrication of the DSSC device involved a sandwich-type photo anode and counter electrode substrates, which were connected by a heat pressing machine together with Surlyn ${ }^{\circledR}$ plastic. Until screening the polymer adhesive, Iodine electrolyte was placed between the photo anode and the counter electrode substrates. Figure 1 displays the synthesis process of $A$. catechu dye.

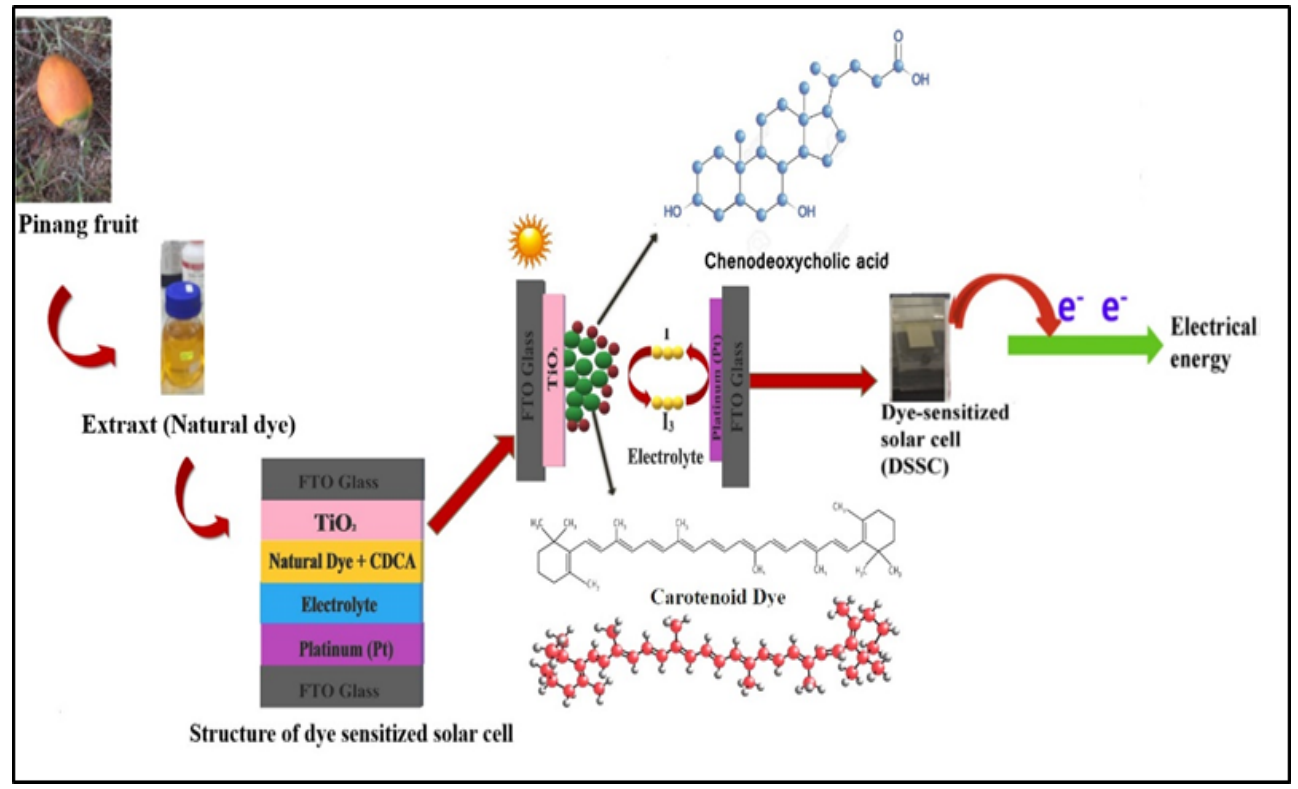

FIGURE 1. Procedures for $A$. catechu dye synthesis

\section{CHARACTERIZATIONS}

The absorption spectra of the freshly prepared A. catechu dye suspension were obtained through UV-visible (UVVis) spectroscopy (Perkin Elmer, Lambda 35), in the wavelength range of (200-900) $\mathrm{nm}$. To detect the functional groups contained inside $A$. catechu, Fourier- transform infrared (FTIR) spectroscopy in the wavenumber region of $4000-400 \mathrm{~cm}^{-1}$ (NICOLET 6700) was performed. PL 
emission spectra of the dye suspension were determined using a spectrometer (Model: fluorescence 50560). The $\mathrm{CV}$ of the working and counter electrodes were analyzed by Solartron (Model, MOULAB H032850) in threeelectrode cell configuration (reference electrode; $\mathrm{Ag}^{+}$/ $\mathrm{AgCl}$, glassy carbon, and $\mathrm{Pt}$ wire). A phosphate buffer solution was used as an electrolyte (0.2 M, pH 7.2). The voltage was between $(-1.0$ and $+1.0 \mathrm{~V})$ at a scan rate of $50 \mathrm{mVs}^{-1}$. The IPCE was measured using a calibrated photodiode within the range of 300-1100 nm (Bentham: PVE300 EQE (ICPE) IQE). The current-voltage (I-V) characteristics of DSSC have been tested on a direct solar illumination of $100 \mathrm{Wm}^{-2}$ using an I-V tester (XES - 40S1 S / N: 074, Keithley 2400 Source Meter Model 2401). All processes at room temperature was performed.

\section{RESULTS AND DISCUSSION}

\section{CDCA EFFECTS ON THE ABSORPTION OF EXTRACTION DYE}

Figure 2 displays the UV-Vis absorption spectra of $A$. catechu dye containing different concentrations of CDCA within the wavelength range of 300-600 $\mathrm{nm}$. The figure shows three distinguishable peaks at $375,398,422$, and $443 \mathrm{~nm}$, with a slightly weak shoulder absorption band of $464 \mathrm{~nm}$. The standard peaks at 400-500 $\mathrm{nm}$ indicate the existence of carotenoids (Sharma \& Ghoshal 2020). The absorption spectrum of $A$. catechu indicates an absorption of the natural dye before and after the introduction of CDCA in the green and violet regions of the spectrum, as well as in the blue and indigo ones (Figure 2). The decrements in the absorption spectra of $A$. catechu dye with CDCA concentrations of 0.5 and $0.1 \mathrm{mM}$ at $423 \mathrm{~nm}$ are approximately equal. The addition of $1.0 \mathrm{mM}$ of CDCA yields the lowest absorbance after adding $1.5 \mathrm{mM}$. The adsorption capacity of the four dyes gradually reduces with the increase in CDCA concentration in the dye solution; such decrement is an indication of the competition between dye molecules and CDCA. The wavelength position of the main absorption peak of the carotenoids is not correlated with the polarity of the solvent, but rather dependent on the type and water content. The result of our previous work showed that the binding of dye molecules enhances the red shift in the visible region when methanol is used as the extraction solvent (Najm et al. 2020b). Carotenoid dissolves easily in methanol, with poor solubility in ethanol. The absorption effect can therefore be clarified by the interactions between the dye molecule and the solvent in order to stabilize the ground conditions (Yamazaki et al. 2007). The absorption spectrum decreases significantly when the co-adsorbent concentration is increased to 1.5 $\mathrm{mM}$. This spectral evolution is consistent with the findings of previous studies (Chevrier et al. 2020). The co-adsorbent decreases dye adsorption through a competitive process of anchoring, which reduces dye concentration and dye aggregation in $\mathrm{TiO}_{2}$ surface.

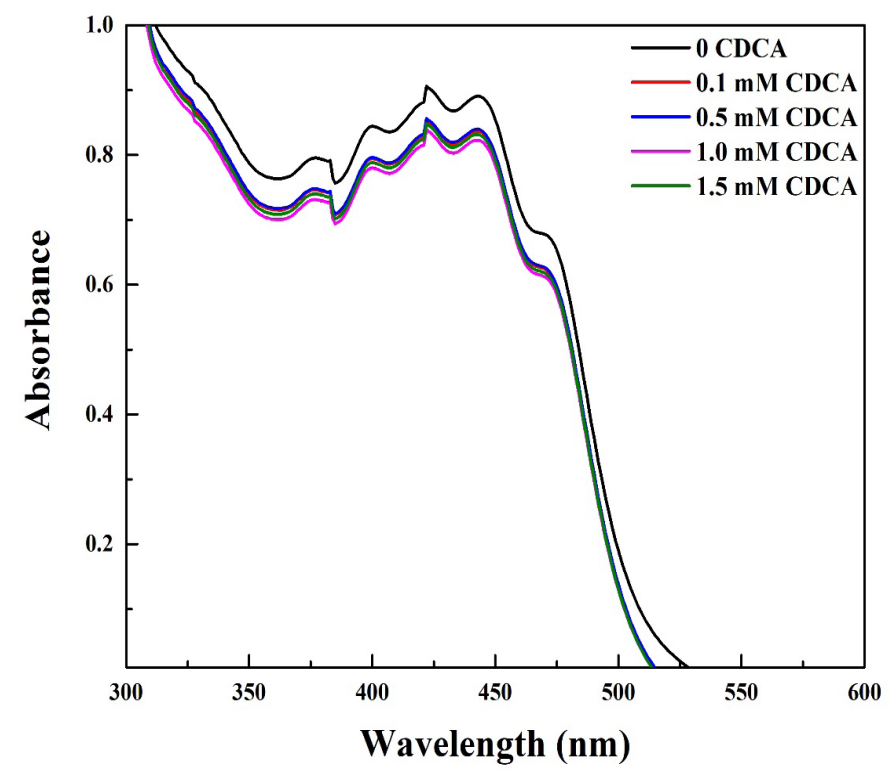

FIGURE 2. UV-vis spectra of $A$. catechu dye with various CDCA concentrations 


\section{FTIR SPECTRA OF $A$. catechu DYE WITH CDCA}

FTIR spectroscopy is suitable for examining chemical interactions in heterogeneous materials. The FTIR spectra of $A$. catechu dye are displays in Figure 3, in the wavelength range of $1000-4000 \mathrm{~cm}^{-1}$ with various CDCA concentrations. The presence and transmission of functional chemical groups binding vibrations are a basic indication of the interaction between natural dye and CDCA molecules. FTIR spectroscopy results indicate that the extracted natural dye is attributed to carotenoid dye, due to the color of natural dye extracted and the functional group has been found in the structure of dye. Carotenoids provide the best photo-sensitized effect due to their carboxylic groups that can easily bind to the $\mathrm{TiO}_{2}$ film surface; this effect results in the photo-current shortcircuit (Yamazaki et al. 2007). The findings imply that the trend of each sample is approximately the same as the transmission profiles, except when the CDCA concentration is increased to $1.5 \mathrm{mM}$. In such case, the sharpness of the peaks declines without losing any functional group. This phenomenon is due to the strong intermolecular hydrogen bonding of the CDCA, which forms an extensive crystalline structure (Oguchi et al. 2003). Extracting using ethanol results in the appearance of additional functional groups. For example, the ether (C-O-C) is observed in two vibration bands (1044.09 and $\left.1089.16 \mathrm{~cm}^{-1}\right)$. In the previous work, which involved extracting using methanol, only one vibration band was observed $\left(1021.25 \mathrm{~cm}^{-1}\right)$. Similarly, aldehyde appears in the two vibration bands assigned at 1453.84 and $1379.4 \mathrm{~cm}^{-1}$ (Vidhya \& Narain 2011). Amides (carboxylic acid derivatives) are observed in A. catechu dye at $1655.89 \mathrm{~cm}^{-1}$ after using ethanol as the extraction solvent. The existence of the hydrogen-bound carboxylic group signals and the surface-adsorbed carboxylate stretching indicates the consistency of intermolecular patterns of aggregation, with slight variability according to the amount of CDCA added. Ismail et al. (2018) examined the impact of mangosteen fruit as a natural dye with various CDCA concentrations. The results displays good role in the device; this could be attributed to CDCA which played a role in the generation of additional $\mathrm{O}-\mathrm{H}$ bonds in the color sensitizer associated with the conductive titanium surface (Ismail et al. 2018). In addition, the bands found in 2974.69 and $3334.59 \mathrm{~cm}^{-1}$ were $\mathrm{C}-\mathrm{H}$ and $\mathrm{O}-\mathrm{H}$ stretching, which due to the presence of the hydroxyl groups were strongly bound to $\mathrm{TiO}_{2}$ surface (Hosseinpanahi et al. 2017). In the present study, the specific transmittance band occurrences confirm successful CDCA adsorption on the surface $A$. catechu dye and change in chemical structures enhancing cell efficiency. The three groups $(-\mathrm{OH}, \mathrm{C}=\mathrm{O}$, and $-\mathrm{COOH})$ used to prepare all dye phases.

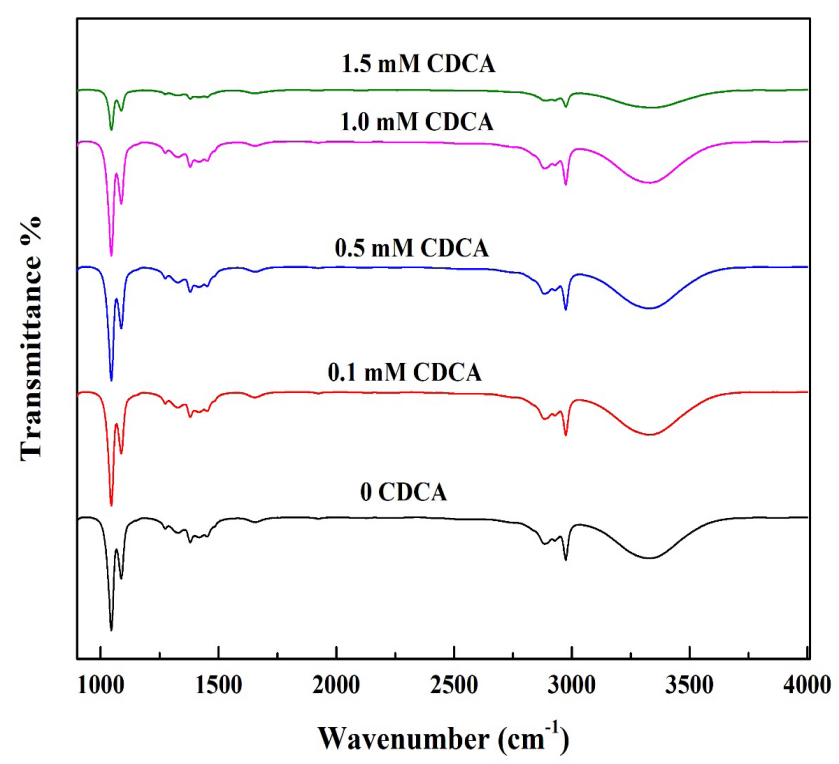

FIGURE 3. FTIR spectra of $A$. catechu dye with CDCA

PL SPECTRA OF $A$. catech $u$ DYE WITH AND WITHOUT CDCA

The PL spectra were obtained to investigate the $\mathrm{e}^{-}-\mathrm{h}^{+}$ pair recombination in $A$. catechu dye with CDCA (Figure
4). The dramatic recombination of the photo-induced charging carriers produces absorption spectra in the range of $650-700 \mathrm{~nm}$. In fact, there is no shift of all curves but 
there are fluctuations of peaks due to including different concentration of CDCA. In addition, PL emission peaks are observed at $673 \mathrm{~nm}$. The peak wavelength $(\lambda)$ is used to measure the dye's energy band gap $(E g)$.

$$
\mathrm{E}_{\mathrm{g}}=\frac{\mathrm{hc}}{\lambda}
$$

where $\mathrm{h}$ is Planck's constant $\left(6.62607004 \times 10^{-34} \mathrm{~m}^{2} \mathrm{~kg}\right.$ $\left.\mathrm{s}^{-1}\right)$; $\mathrm{c}$ is the light speed $\left(3.00 \times 10^{8} \mathrm{~ms}^{-1}\right)$; and $\lambda$ is the wavelength of the highest PL spectrum.

After adding $0.5 \mathrm{mM}$ of CDCA, the high PL peak intensity of $A$. catechu dye suspension indicates a decreased recombination rate of the photogenerated carrier. The PL intensity decreases as the CDCA concentration increases, which indicate a reduction in the $\mathrm{e}^{-}-\mathrm{h}^{+}$recombination rate. Opposite results are observed when methanol is used in the extraction process instead of ethanol. This phenomenon can be ascribed to the holes' occupation of the oxygen vacancy, which results in a lower amount or volume of holes compared with the amount that can be obtained in normal cases. In conclusion, providing an opportunity to improve the mobility of electrons leads to reduced recombination of charging carriers (Mercado et al. 2012). The injection of excited CDCA electrons into the dye conductive band is assumed to be facilitated by the presence of the Schottky barrier at the CDCA/dye interface, which provides a unidirectional route for CDCA electrons to the dye conductive band (Du et al. 2006). Furthermore, the improvements in the chemical compound structures of $A$. catechu contribute to the increase in PL intensity at different CDCA concentrations. Although there is formation of Schottky barrier in CDCA/dye but still not enough to make it is shifting in order to enhance the band gap.

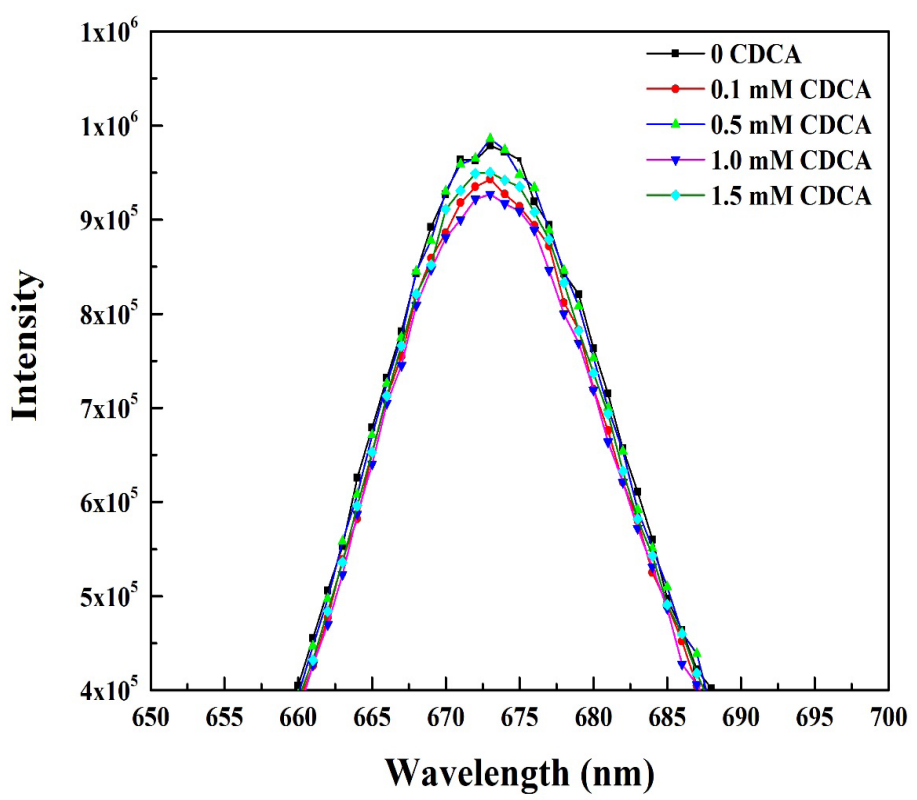

FIGURE 4. PL spectra of $A$. catechu dye with CDCA

\section{ELECTROCHEMICAL CHARACTERISTICS OF $A$. catech $u$ DYE WITH CDCA}

The effect of CDCA concentrations on the electrochemical properties of $A$. catechu dye were examined (Figure 5), and the suspension of the $A$. catechu dye sensitizer was analyzed through CV analyses. These analyses provide the important information about the redox behavior of A. catechu dye. The present study offers comprehensive knowledge of electron transport pathways from the molecules of excited dye to the conducting band (CB) of $\mathrm{TiO}_{2}$. Figure 5 displays the $\mathrm{CV}$ curves of $A$. catechu dye at different CDCA concentrations within $-1.0-1.0 \mathrm{~V}$ from 0.1 to $1.5 \mathrm{mM}$.
We used $E_{\mathrm{g}}$ formula from the PL Spectral Analysis to calculate the highest occupied Molecular Orbital (HOMO) and the lowest unoccupied Molecular Orbital (LUMO) levels ( $\mathrm{Li}$ et al. 2013).

$$
\begin{aligned}
& E_{\text {Номо }}=-e\left(E_{\text {ox }}^{\text {onset }}+4.4\right) \\
& E_{\text {цомо }}=E_{\text {Номо }}+E_{g}
\end{aligned}
$$

The estimated results show that CDCA influences the HOMO and LUMO levels (Table 1). 


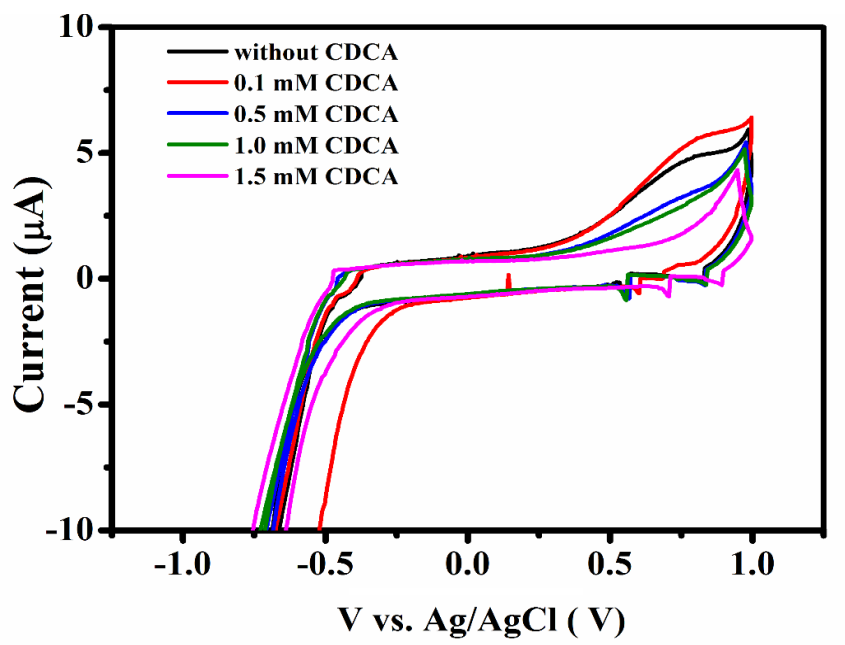

FIGURE 5. CV curve of the properties of the dye suspension with CDCA in ethanol

TABLE 1. Carboxyl group, band gap and CV parameters of the $A$. catechu dye suspension with various concentrations

\begin{tabular}{lccccc}
\hline \multirow{2}{*}{ Criterion } & A. catechu dye & A. catechu dye & A. catech $u$ dye & A. catech $u$ dye & A. catechu dye \\
& & $+0.1 \mathrm{mM} \mathrm{CDCA}$ & $+0.5 \mathrm{mM} \mathrm{CDCA}$ & $+1.0 \mathrm{mM} \mathrm{CDCA}$ & $+1.5 \mathrm{mM} \mathrm{CDCA}$ \\
\hline Carboxyl Group & 1655.98 & 1658.03 & 1655.98 & 1655.98 & 1654.62 \\
Band Gap (eV) & 1.845 & 1.845 & 1.845 & 1.845 & 1.848 \\
HOMO (eV) & -4.599 & -4.609 & -4.644 & -4.659 & -4.679 \\
LUMO (eV) & -2.754 & -2.764 & -2.799 & -2.814 & -2.831 \\
\hline
\end{tabular}

The LUMO and HOMO levels range from -2.83 to $-2.75 \mathrm{eV}$ and from -4.67 to $-4.59 \mathrm{eV}$, respectively, and the $E_{g}$ between them is $1.84 \mathrm{eV}$, which is the photo-effective energy when the photon in the sensitizer is absorbed. The results show that the level of LUMO of the dye provides the electrons with appropriate thermodynamic potential from excited molecular conditions to $\mathrm{TiO}_{2} \mathrm{CB}$. CV results indicate that the HOMO energy is below the $\mathrm{I}^{-} / \mathrm{I}^{-}$potentials in all CDCA-integrated dyes, suggesting that the driver force to regenerate their carrier is suitable (Zhang et al. 2009). The wider bandgap, the lower the dye's extinction coefficient and absorption. Such findings correspond to the results of the previous study (Najm et al. 2020b). In view of the intermolecular interactions induced by surface conditions, which imply deep HOMO levels of energy and high oxidation potentials, dye-CDCA display changes in the anodic and cathodic peaks (Su'ait et al. 2015). The findings also show that the intercalating CDCA particles in the dye enhance the charge transmission, owing to the improved coloration conductivity and the equilibrium of the interfacial energy levels (Guo et al. 2010). CV profiles for all samples display a symmetrical and broad redox reaction, which results in electro growth at different concentrations that increase the action of the redox. Average amounts of maximum visible absorption intensity with both HOMO and LUMO were recorded at A. catechu dye $+1.5 \mathrm{mM}$ CDCA (Table 1 ), which led to highest band gap indicated from all samples we measured. Therefore, in this study, this CDCA concentration is the most appropriate for fabricating the cells.

$$
\text { IPCE }
$$

IPCE was evaluated to observe incident light conversion into electrical energy at the recommended wavelength for A. catechu dyes without and with $1.5 \mathrm{mM}$ CDCA (Figure 6). The IPCE values are obtained as (Vittal \& Ho 2017)

$$
\operatorname{IPCE}(\%)=\frac{1240(\mathrm{eVnm}) \times J}{\mathrm{I} \times \lambda} \times 100 \%
$$


where I $\left(\mathrm{mWcm}^{-2}\right)$ represents monochromatic light intensity and $\mathrm{J}\left(\mathrm{mA} / \mathrm{cm}^{2}\right)$ corresponds to $J_{s c}$ with the wavelength of monochromatic irradiation $\lambda(\mathrm{nm})$. IPCE result exhibits a high absorption of incident light energy in the light wavelength of 300-400 $\mathrm{nm}$ for $A$. catechu dyes without and with $1.5 \mathrm{mM}$ of CDCA.

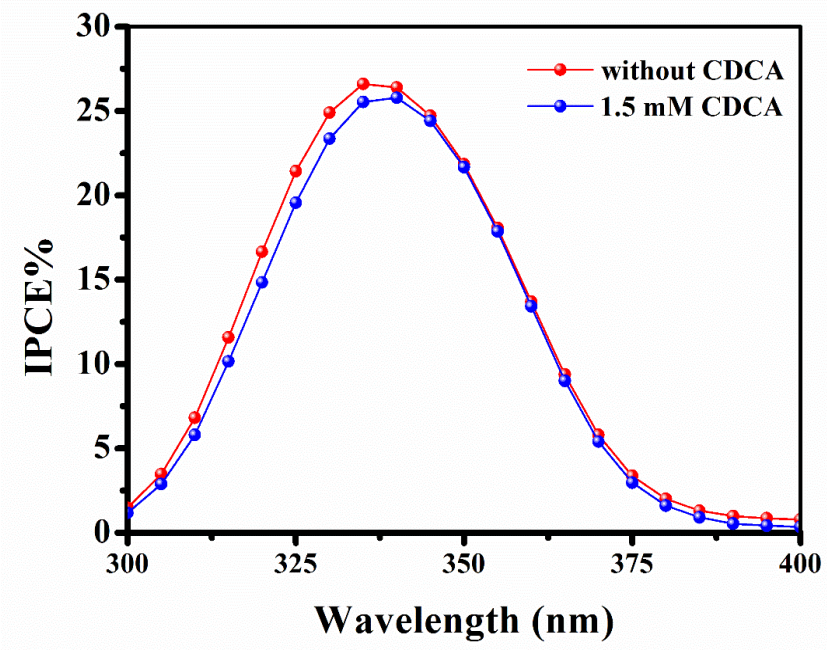

FIGURE 6. IPCE curves for DSSC

Moreover, the IPCE onset of the DSSC in both cases is at $337 \mathrm{~nm}$. To reduce the charging levels of recombination and enhance the IPCE values, an effective approach must be implemented to inhibit dye aggregation. The co-adsorption of CDCA is one of the approaches that can be adopted. The IPCE of pure A catechu is $26.46 \%$, whereas that of the dye soaked with CDCA for 5 days decreased to $25.63 \%$. Due to the presence of CDCA as co-adsorbent, which improves intermolecular energy transfer and decreases electron injection efficiency, the decreased quantum yield can be correlated with an increasing dye aggregation. This influence does not compensate the loss of the light harvest due to the low dye content of the $\mathrm{TiO}_{2}$ photoanode with CDCA, thereby causing the present density to decrease. Such a mechanism can establish a substantial discrepancy between the electrolyte recombination of $\mathrm{I}^{3-i n j e c t i n g}$ electrons and
$\mathrm{TiO}_{2}$ electron transport rates. The different proportion of IPCE is due to varying quantities of natural color on the $\mathrm{TiO}_{2}$ surface. The adsorption amount of sensitizer dye directly influences the quantum efficiency of the DSSCs. A gap in the device performance is observed after comparing the obtained result with that of N719 dye, whose IPCE reached $80 \%$ (Krishna et al. 2017).

\section{$J-V$ CHARACTERISTICS}

A. catechu dyes with and without CDCA was used as a DSSC photosensitizer to study and evaluate the PV properties. Figure 7 shows the I-V DSSC sensitized curves of natural dye, which display the maximum value of CDCA (1.5mM) obtained at two altered periods.

The calculation of I-V was achieved under A.M. 1.5 solar illumination. The DSSC performance was estimated in Table 2.

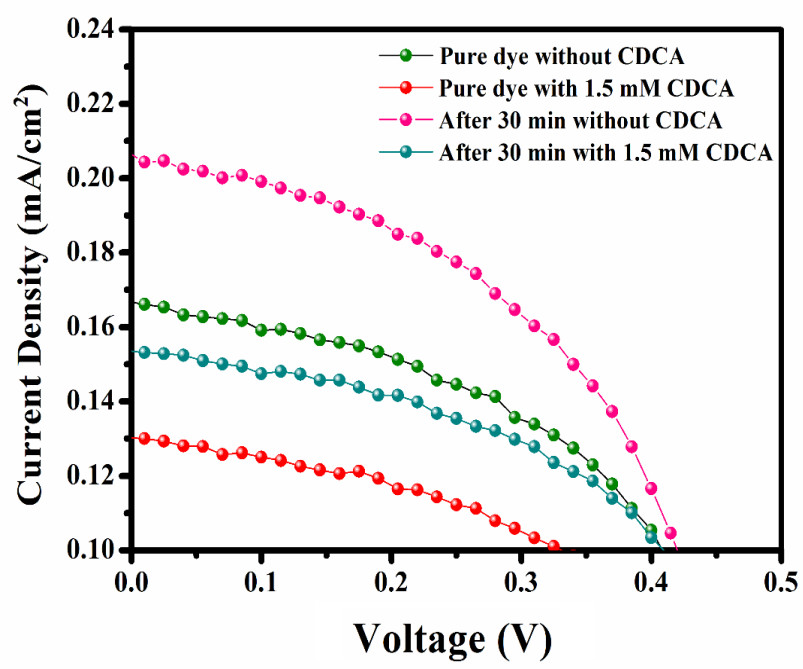

FIGURE 7. I-V curves of DSSC 
TABLE 2. Photovoltaic parameters of the DSSCs with $1.5 \mathrm{mM}$ CDCA for two various periods

\begin{tabular}{cccccc}
\hline DSSC & CDCA $(\mathrm{mM})$ & $J_{s c}\left(\mathrm{~mA} / \mathrm{cm}^{2}\right)$ & $V_{o c}(\mathrm{~V})$ & $F F(\%)$ & $\eta(\%)$ \\
\hline At time 0 & 0 & 0.2 & 0.483 & 72.35 & 0.066 \\
\multirow{3}{*}{ After 30 min } & 1.5 & 0.1 & 0.487 & 61.06 & 0.028 \\
& 0 & 0.2 & 0.478 & 68.83 & 0.065 \\
& 1.5 & 0.2 & 0.5 & 76.44 & 0.076 \\
\hline
\end{tabular}

The dyes without and with $1.5 \mathrm{mM}$ of CDCA achieve overall efficiencies of approximately $0.066 \%$ and $0.028 \%$, respectively. The carrier transport with inadequate number of attaching groups results in a decrease in PV efficiency. Furthermore, due to the lack of the anchor groups, the diffusion of electrons from the dye molecules onto the $\mathrm{TiO}_{2}$ surface decreased. Consequently, $J_{s c}$ decreases. The number of electrons should expand by increasing the amount of CDCA because of the available conduction channels, the conductive surface of $\mathrm{TiO}_{2}$ and bonds between the dye sensitizer molecules. Due to the conductive channel available, the conductive surface of $\mathrm{TiO}_{2}$ and the interaction of the groups between the dye sensitizer molecules, the number of electrons will increase (San Esteban \& Enriquez 2013). While the CDCA content is extremely high, Voc does not change significantly, indicating that CDCA does not increase the effectiveness of the recombination (Gómez-Ortíz et al. 2010). Pugliese et al. (2013) used the same approach and argued that the increased electron injection in the cell efficiency can be attributed to the rise in $J_{s c}$ due to the co-adsorption during the loading time. The required time for preparing the dye was set as $30 \mathrm{~min}$. Through this period, the suppression of dye aggregations by decreasing the electrons is adequate to achieve the low resistance of the cell sensitized by CDCA-integrated dyes (Mikroyannidis et al. 2011).

$V_{\text {oc }}$ is expected to increase, because the $V_{\text {oc }}$ is determined by the difference between the electrolyte's redox potential and the $\mathrm{TiO}_{2}$ energy level, which indicates that the co-adsorbed CDCA could serve as an electron transport medium producing higher current and providing higher power conversion efficiency with increased loading time, as the CDCA effect could also be observed in the dye-adsorption step and somehow also incorporated into the dye- $\mathrm{TiO}_{2}$ interface in the dyeadsorption step.

Prolonging the loading time leads to the full process of disaggregation, and CDCA is responsible for the system in dispute. Indeed, this conflict does not allow the dye sensitizer to be attached effectively to the semiconductor surface, thereby increasing cell performance. Therefore, choosing the right time will improve the efficiency variance of cells from $0.065 \%$ to $0.076 \%$, without and with CDCA incorporation. The values of photochemical metal composite parameters obtained from different plants and performed for DSSCs are described in Table 3.

TABLE 3. Photovoltaic parameters of the natural dye-based DSSC extracted from different plants

\begin{tabular}{|c|c|c|c|c|c|}
\hline Natural dye & $J_{s c}\left(\mathrm{~mA} \mathrm{~cm}^{-2}\right)$ & $V_{o c}(\mathrm{~V})$ & $F F$ & $\eta(\%)$ & References \\
\hline Eggplant peels & 3.4 & 0.35 & 40 & 0.47 & $\begin{array}{c}\text { (Calogero \& di Marco } \\
\text { 2008) }\end{array}$ \\
\hline Tangerine peels & 0.74 & 0.59 & 63 & 0.27 & (Zhou et al. 2011) \\
\hline Annatto & 0.53 & 0.56 & 66 & 0.19 & (Zhou et al. 2011) \\
\hline Rosella & 1.63 & 0.40 & 57 & 0.37 & (Wongcharee et al. 2007) \\
\hline Dragon fruit & 0.20 & 0.22 & 30 & 0.22 & $\begin{array}{l}\text { (Riyaz Ahmad \& } \\
\text { Nafarizal 2010) }\end{array}$ \\
\hline Ipomoea & 0.91 & 0.54 & 0.56 & 0.28 & (Hao et al. 2008) \\
\hline Delonix regia & 1.33 & 0.30 & 0.39 & 0.317 & (Senthil et al. 2011) \\
\hline Begonia & 0.63 & 0.537 & 0.72 & 0.24 & (Zhou et al. 2011) \\
\hline Spinach & 1.12 & 0.565 & 0.59 & 0.318 & (Chang et al. 2010) \\
\hline Cherries & 0.466 & 0.565 & 0.38 & 0.181 & (Jasim 2012) \\
\hline K. japonica & 0.5597 & 0.5839 & 0.68 & 0.22 & (Hemalatha et al. 2012) \\
\hline
\end{tabular}




\section{CONCLUSION}

This study showed that the pinang palm (A. catechu) can work as a new class of high-performance DSSC sensitizer. Dye adsorption and sensitization were investigated by adding CDCA at different concentrations. At a CDCA concentration of $1.5 \mathrm{mM}$, optimum cell efficiency was achieved. The use of CDCA has been successful in increasing the attachments of charge transport groups within dye molecules, thereby enhancing electron transfer between photosensitizer molecules and $\mathrm{TiO}_{2}$ surface. Electrical and optical investigation was carried out to evaluate the co-absorbing effect on the enhancement of DSSC. CV analysis was used to show each sensitizer's LUMO and HOMO levels. The photochemical properties yielded $26.46 \%$ IPCE. A. catechu sensitizer reported $25.63 \%$ IPCE after adding $1.5 \mathrm{mM}$ CDCA. The results showed that dye characteristics declined after CDCA was added, which could be due to dye aggregation in $\mathrm{TiO}_{2}$ surface. This aggregation also impacted charging transfer efficiency. CDCA took much time to suppress aggregation. Co-adsorbent material quantified the PV efficiency at a loading time of $30 \mathrm{~min} .0 .065 \%$ maximum efficiency was achieved without co-adsorbent. This efficiency improved by $1.5 \mathrm{mM}$ of CDCA to $0.076 \%$. CDCA can attend as a catalyst for increasing the efficiency of the DSSC device by incorporating additional anchoring abilities with natural dye after optimizing the loading time. The CDCA modification of the dye structure and the subsequent production of enhanced visible light indicate the benefits of CDCA for DSSCs. However, the obtained efficiency of natural dye is not sufficient to surpass that of artificial sensitizers. Future studies should therefore increase the amount of CDCA and purify the natural dye sensitizers or add a noble metal as a co-sensitizer to a photosensitizer to further improve the efficiency.

\section{ACKNOWLEDGEMENTS}

The authors acknowledged the contributions and support from Universiti Kebangsaan Malaysia (UKM) for funding this research under the auspices of Dana Impak Perdana Grant (DIP-2019-025).

\section{REFERENCES}

Amarasinghe, H.K., Usgodaarachchi, U.S., Johnson, N.W., Lalloo, R. \& Warnakulasuriya, S. 2010. Betel-quid chewing with or without tobacco is a major risk factor for oral potentially malignant disorders in Sri Lanka: A case-control study. Oral oncology 46(4): 297-301.

Çakar, S. \& Özacar, M. 2016. Fe-tannic acid complex dye as photo sensitizer for different morphological $\mathrm{ZnO}$ based DSSCs. Spectrochimica Acta Part A: Molecular and Biomolecular Spectroscopy 163: 79-88.

Calogero, G. \& di Marco, G. 2008. Red Sicilian orange and purple eggplant fruits as natural sensitizers for dye- sensitized solar cells. Solar Energy Materials and Solar Cells 92(11): 1341-1346.

Chang, H., Wu, H.M., Chen, T.L., Huang, K.D., Jwo, C.S. \& Lo, Y.J. 2010. Dye-sensitized solar cell using natural dyes extracted from spinach and ipomoea. Journal of Alloys and Compounds 495(2): 606-610.

Chevrier, M., Fattori, A., Lasser, L., Kotras, C., Rose, C., Cangiotti, M. \& Dubois, P. 2020. In depth analysis of photovoltaic performance of chlorophyll derivative-based "all solid-state" dye-sensitized solar cells. Molecules 25(1): 198.

Du, J., Zhang, J., Liu, Z., Han, B., Jiang, T. \& Huang, Y. 2006. Controlled synthesis of $\mathrm{Ag} / \mathrm{TiO} 2$ core-shell nanowires with smooth and bristled surfaces via a one-step solution route. Langmuir 22(3): 1307-1312.

Gómez-Ortíz, N.M., Vázquez-Maldonado, I.A., Pérez-Espadas, A.R., Mena-Rejón, G.J., Azamar-Barrios, J.A. \& Oskam, G. 2010. Dye-sensitized solar cells with natural dyes extracted from achiote seeds. Solar Energy Materials and Solar Cells 94(1): 40-44.

Grätzel, M. 2003. Dye-sensitized solar cells. Journal of Photochemistry and Photobiology C: Photochemistry Reviews 4(2): 145-153.

Green, M.A., Dunlop, E.D., Levi, D.H., Hohl-Ebinger, J., Yoshita, M. \& Ho-Baillie, A.W. 2020. Solar cell efficiency tables (Version 55). Progress in Photovoltaics 28(1): 3-15.

Guo, S., Wen, D., Zhai, Y., Dong, S. \& Wang, E. 2010. Platinum nanoparticle ensemble-on-graphene hybrid nanosheet: Onepot, rapid synthesis, and used as new electrode material for electrochemical sensing. ACS Nano 4(7): 3959-3968.

Gürses, A., Açıkyıldız, M., Güneş, K. \& Gürses, M.S. 2016. Dyes and pigments: Their structure and properties. In Dyes and Pigments. Berlin: Springer. pp. 13-29.

Hao, D.C., Xiao, P.G., Huang B.L., Ge, G.B. \& Yang, L. 2008. Interspecific relationships and origins of Taxaceae and Cephalotaxaceae revealed by partitioned Bayesian analyses of chloroplast and nuclear DNA sequences. Plant Systematics and Evolution 276: 89-104.

Hemalatha, K.V., Karthick, S.N., Raj, C.J., Hong, N.Y., Kim, S.K. \& Kim, H.J. 2012. Performance of Kerria japonica and Rosa chinensis flower dyes as sensitizers for dye-sensitized solar cells. Spectrochimica Acta Part A: Molecular and Biomolecular Spectroscopy 96: 305-309.

Holi, A.M., Al-Zahrani, A.A., Najm, A.S., Chelvanathan, P. \& Amin, N. 2020. PbS/CdS/ZnO nanowire arrays: Synthesis, structural, optical, electrical, and photoelectrochemical properties. Chemical Physics Letters 750: 137486.

Hosseinpanahi, K., Abbaspour-Fard, M.H., Feizy, J. \& Reza Golzarian, M. 2017. Dye-sensitized solar cell using saffron petal extract as a novel natural sensitizer. Journal of Solar Energy Engineering 139: 021009.

Ismail, M., Ludin, N.A., Norul Hisham H., Adib, I.M. \& Sopian, K. 2018. The effect of chenodeoxycholic acid (CDCA) in Mangosteen (Garcinia mangostana) pericarps sensitizer for dye-sensitized solar cell (DSSC). Journal of Physics Conference Series 1083. Bristol: IOP Science. p. 012018.

Ismail, M., Ludin, N.A., Hamid, N.H., Ibrahim, M.A., Zulfakar, M.S., Mohamed, N.M. \& Sopian, K. 2017. Characterizations of natural dye from Garcinia mangostana with graphene 
oxide (GO) as sensitizer in dye-sensitizer solar cells. AIP Conference Proceedings 1838. Melville: AIP Publishing LLC. p. 0120017.

Jasim, K.E. 2012. Natural dye-sensitized solar cell based on nanocrystalline $\mathrm{TiO}_{2}$. Sains Malaysiana 41(8): 1011-1016.

Jung, J.S. 2017. Making of natural dyeing scarves by tie-dyeing technique. MATEC Web of Conferences 108. Les Ulis: EDP Sciences. p. 03006.

Krishna, N.V., Krishna, J.V.S., Mrinalini, M., Prasanthkumar, S. \& Giribabu, L. 2017. Role of co-sensitizers in dye-sensitized solar cells. ChemSusChem 10(23): 4668-4689.

Li, J., Wu, W., Yang, J., Tang, J., Long, Y. \& Hua, J. 2011. Effect of chenodeoxycholic acid (CDCA) additive on phenothiazine dyes sensitized photovoltaic performance. Science China Chemistry 54: 699.

Li, Y., Ku, S.H., Chen, S.M., Ali, M.A. \& AlHemaid, F.M. 2013. Photoelectrochemistry for red cabbage extract as natural dye to develop a dye-sensitized solar cells. International Journal of Electrochemical Science 8: 1237-1245.

Mahir Faris Abdullah, Rozli Zulkifli, Zambri Harun, Shahrir Abdullah, Wan Aizon Wan Ghopa, Asmaa Soheil Najm \& Noor Humam Sulaiman. 2019. Impact of the $\mathrm{TiO}_{2}$ nanosolution concentration on heat transfer enhancement of the twin impingement jet of a heated aluminum plate. Micromachines 10: 176

Mercado, C.C., Knorr, F.J., McHale, J.L., Usmani, S.M., Ichimura, A.S. \& Saraf, L.V. 2012. Location of hole and electron traps on nanocrystalline anatase $\mathrm{TiO}_{2}$. The Journal of Physical Chemistry C 116(19): 10796-10804.

Mikroyannidis, J.A., Suresh, P., Roy, M.S. \& Sharma, G.D. 2011. New photosensitizer with phenylenebisthiophene central unit and cyanovinylene 4-nitrophenyl terminal units for dye-sensitized solar cells. Electrochimica Acta 56(16): 5616-5623.

Muhammad, N., Muh Zakir, M., Maulidiyah, M., Nurjannah, M. \& Dwiprayogo, W. 2016. Plasmonic Silver-N/TiO 2 Effect on photoelectrocatalytic oxidation reaction. J. Mater. Environ. Sci. 7(9): 3334-3343.

Najm, A.S., Ludin, N.A., Abdullah, M.F., Almessiere, M.A., Ahmed, N.M. \& Al-Alwani, M.A. 2020a. Areca catechu extracted natural new sensitizer for dye-sensitized solar cell: Performance evaluation. Journal of Materials Science: Materials in Electronics 31: 3564-3575.

Najm, A.S., Moria, H. \& Ludin, N.A. 2020b. Areca catechu as photovoltaic sensitizer for dye-sensitized solar cell (DSSC). Biointerface Research in Applied Chemistry 10(3): 56365639.

Najm, A.S., Mohamad, A.B. \& Ludin, N.A. 2017. The extraction and absorption study of natural dye from Areca catechu for dye sensitized solar cell application. AIP Conference Proceedings Series 1838. Melville: AIP Publishing LLC. p. 020019

Narayan, M.R. 2012. Dye sensitized solar cells based on natural photosensitizers. Renewable and Sustainable Energy Reviews 16: 208-215.

Oguchi, T., Sasaki, N., Hara, T., Tozuka, Y. \& Yamamoto, K. 2003. Differentiated thermal crystallization from amorphous chenodeoxycholic acid between the ground specimens derived from the polymorphs. International Journal of Pharmaceutics 253(1-2): 81-88.

Portillo-Cortez, K., Martinez, A., Dutt, A. \& Santana, G. 2019. N719 Derivatives for application in a dye-sensitized solar cell (DSSC): A theoretical study. The Journal of Physical Chemistry A 123(51): 10930-10939.

Pugliese, D., Shahzad, N., Sacco, A., Musso, G., Lamberti, A., Caputo, G. \& Pirri, C.F. 2013. Fast $\mathrm{TiO}_{2}$ sensitization using the semisquaric acid as anchoring group. International Journal of Photoenergy 2013: 871526.

Purgato, F.L.S., Pronier, S., Olivi, P., de Andrade, A.R., Léger, J.M., Tremiliosi-Filho, G., Kokoh, K.B. 2012. Direct ethanol fuel cell: Electrochemical performance at $90{ }^{\circ} \mathrm{C}$ on Pt and $\mathrm{PtSn} / \mathrm{C}$ electrocatalysts. Journal of Power Sources 198: 95-99.

Qu, S., Wu, W., Hua, J., Kong, C., Long, Y. \& Tian, H. 2010 New diketopyrrolopyrrole (DPP) dyes for efficient dyesensitized solar cells. The Journal of Physical Chemistry $C$ 114(2): 1343-1349.

Riyaz Ahmad Mohamed Ali \& Nafarizal Nayan. 2010. Fabrication and analysis of dye-sensitized solar cell using natural dye extracted from dragon fruit. International Journal of Integrated Engineering 2(3): 55-62.

Safie, N.E., Hamid, N.H., Sepeai, S., Teridi, M.A.M., Ibrahim, M.A., Sopian, K. \& Arakawa, H. 2017. Energy levels of natural sensitizers extracted from rengas (Gluta spp.) and mengkulang (Heritiera elata) wood for dye-sensitized solar cells. Materials for Renewable and Sustainable Energy 6: 5 .

San Esteban. A.C.M. \& Enriquez, E.P. 2013. Grapheneanthocyanin mixture as photosensitizer for dye-sensitized solar cell. Solar Energy 98(Part C): 392-399.

Senthil, T.S., Muthukumarasamy, N., Velauthapillai, D., Agilan, S., Thambidurai, M. \& Balasundaraprabhu, R. 2011. Natural dye (cyanidin 3-O-glucoside) sensitized nanocrystalline $\mathrm{TiO}_{2}$ solar cell fabricated using liquid electrolyte/quasi-solid-state polymer electrolyte. Renewable Energy 36(9): 2484-2488.

Sharma, R. \& Ghoshal, G. 2020. Optimization of carotenoids production by Rhodotorula mucilaginosa (MTCC-1403) using agro-industrial waste in bioreactor: A statistical approach. Biotechnology Reports 25: e00407.

Sharma, S., Siwach, B., Ghoshal, S.K. \& Mohan, D. 2017. Dye sensitized solar cells: From genesis to recent drifts. Renewable and Sustainable Energy Reviews 70: 529-537.

Shrestha, J., Shanbhag, T., Shenoy, S., Amuthan, A., Prabhu, K., Sharma, S. \& Kafle, S. 2010. Antiovulatory and abortifacient effects of Areca catechu (betel nut) in female rats. Indian Journal of Pharmacology 42(5): 306-311.

Su'ait, M.S., Rahman, M.Y.A. \& Ahmad, A. 2015. Review on polymer electrolyte in dye-sensitized solar cells (DSSCs). Solar Energy 115: 452-470.

Toor, R.A., Sayyad, M.H., Nasr, N., Sajjad, S., Shah, S.A.A \& Manzoor, T. 2016. Efficiency enhancement of dye sensitized solar cells with a low cost co-adsorbent in N719 dye. International Journal of Sustainable Energy and Environment Research 5(3): 46-50. 
Vidhya, R. \& Narain, A. 2011. Formulation and evaluation of preserved products utilizing under exploited fruit, wood apple (Limoniaacidissima). American-Eurasian J. Agric. \& Environ. Sci. 10(1): 112-118.

Vittal, R. \& Ho, K.C. 2017. Zinc oxide based dye-sensitized solar cells: A review. Renewable and Sustainable Energy Reviews 70: 920-935.

Wang, Z.S., Cui, Y., Dan-oh, Y., Kasada, C., Shinpo, A. \& Hara, K. 2007. Thiophene-functionalized coumarin dye for efficient dye-sensitized solar cells: Electron lifetime improved by coadsorption of deoxycholic acid. The Journal of Physical Chemistry C 111(19): 7224-7230.

Wongcharee, K., Meeyoo, V. \& Chavadej, S. 2007. Dye-sensitized solar cell using natural dyes extracted from rosella and blue pea flowers. Solar Energy Materials and Solar Cells 91(7): 566-571

Yamazaki, E., Murayama, M., Nishikawa, N., Hashimoto, N., Shoyama, M. \& Kurita, O. 2007. Utilization of natural carotenoids as photosensitizers for dye-sensitized solar cells. Solar Energy 81(4): 512-516.

Yum, J.H., Jang, S.R., Humphry-Baker, R., Grätzel, M., Cid, J.J., Torres, T. \& Nazeeruddin, M.K. 2008. Effect of coadsorbent on the photovoltaic performance of zinc pthalocyanine-sensitized solar cells. Langmuir 24(10): 5636-5640.

Zhang, G., Bala, H., Cheng, Y., Shi, D., Lv, X., Yu, Q. \& Wang, P. 2009. High efficiency and stable dye-sensitized solar cells with an organic chromophore featuring a binary $\pi$-conjugated spacer. Chemical Communications 16: 21982200 .

Zhou, H., Wu, L., Gao, Y. \& Ma, T. 2011. Dye-sensitized solar cells using 20 natural dyes as sensitizers. Journal of Photochemistry and Photobiology A: Chemistry 219(2-3): 188-194.

Asmaa Soheil Najm

Department of Electrical Electronic \& Systems Engineering

Faculty of Engineering and Built Environment

Universiti Kebangsaan Malaysia

43600 UKM Bangi, Selangor Darul Ehsan

Malaysia
Norasikin A. Ludin*, Mohd Adib Ibrahim, Mohd Asri Mat Teridi \& Kamaruzzaman Sopian

Solar Energy Research Institute (SERI)

Universiti Kebangsaan Malaysia

43600 UKM Bangi, Selangor Darul Ehsan

Malaysia

Norul Hisham Hamid

Biocomposite Unit

Institute of Tropical Forestry and Forest Products

Universiti Putra Malaysia

43400 UPM Serdang, Selangor Darul Ehsan

Malaysia

\section{Hazim Moria}

Department of Mechanical Engineering Technology

Yanbu Industrial College

Yanbu Al-Sinaiyah 41912

Kingdom of Saudi Arabia

Araa Mebdir Holi

Department of Physics

College of Education

University of Al-Qadisiyah

Al-Diwaniyah, Al-Qadisiyah 58002

Iraq

Asla A. AL-Zahrani

Imam Abdulrahman Bin Faisal University

Eastern Region, Dammam

Saudi Arabia

Hasanain Salah Naeem

School of Chemical Sciences and Food Technology

Faculty of Science and Technology

Universiti Kebangsaan Malaysia

43600 UKM Bangi, Selangor Darul Ehsan

Malaysia

*Corresponding author; email: sheekeen@ukm.edu.my

Received: 12 August 2020

Accepted: 30 August 2020 